\title{
Singing of Incantations in Nordic Tradition
}

\author{
By Anna-Leena Simkala
}

In 1678 Tuomo Jaakonpoika, a crofter, was questioned at the Liminkä Assizes on the subject of witchcraft and the worship of idols, for out in the forest he had constructed and erected a wooden image. At the hearing, Tuomo spoke as follows:

He was so seriously ill that he found relief by bathing seven or eight times a day in steam so hot that the women bathing him were forced to wear mittens. He then requested a certain Simo Pulloinen from Siikajoki to come and bath him - a man often resorted to in cases of serious illness. Before Pulloinen embarked on his task, Tuomo's wife said: 'Cross yourself with iron first in order to seek the Lord's protection.' Then Pulloinen took his sheath, containing two knives, and crossed this thighs and his body three times round in order to prevent himself from catching the disease. Then he cast a lot, placing his cap on the floor and flint therein; thereafter he cast a silver coin on the flint three times. The coin fell thrice with the same side showing, thus indicating the source of the disease. At the same time, sometimes mumbling, sometimes in a loud voice, he recited prayers and incantations, including the Lord's Prayer and the Creed and the following chant:

'Neighty Maria emoinen, puhdas muori puhtukainen tule mulle turvaksi täsä työsäni, anna mulle apua viskaa metinen löyly niin kuin löyly saunan löyly.'
Virgin Mary, Holy Mother, purest of maidens watch over me in this my task, give me help and honey steam as the steam in the sauna.

During the bath Pulloinen went outside for a moment, and said on returning that the disease had come from the forest. Then, in the sauna, Tuomo and Pulloinen made a wooden image about 15 centimetres high, clothed it and then gave it to Tuomo's sister-in-law, ordering her to take it into the forest and tie it with red woollen thread to an alder tree. This she did one thursday, and then departed without looking back.

1 These words are in Finnish, though the rest of the court records are in Swedish. 
It further appeared that Pulloinen had, while curing Tuomo, sung (laulanut):

'nosta pilvi pohjaselta tuo sulka sulalta maalta, Marian makia maito, kipiöitä voitelemaan, pahoja parantamaan.'

(Juvelius 1930, 58 ff.). raise a cloud from the north

bring a feather

from ice-free earth

Mary's sweet milk, to soothe the pain, to cure the evil

This report of the court proceedings published by Einar M. Juvelius in the Chronicles of the Finnish People is one of the earliest accounts of the behaviour of a Finnish tietäjä or sage. Thanks to the liberalmindedness and close observations of Tuomo Jaakon poika, detailed information on the events of a healing rite have been preserved for subsequent generations. Of special interest are his observations on the delivery of the incantations. We see that the Finnish tietäja at the end of the 17th century had recourse to several incantations and prayers during a single healing event, and that he delivered them in different ways, sometimes mumbling under his breath, sometimes chanting or singing in a loud voice.

\section{The spoken incantation}

The above account is significant in the sense that spoken recitation later became established as the mode of delivering the Finnish incantation. The ordinary incantations connected with everyday life in agrarian society were recited with little ceremony, in a mumble, a whisper, as if "rattling it off inside the mouth" (Wartiainen 1926, 78) Christian Lencquist drew a parallel between the mumbling of incantations and Christian influence in a description of Finnish folk belief published in 1782: "They are known in Finnish by the name of lugut. They were uttered not by singing and not in a loud voice, but in a subdued mutter, with great piety and with heads bared, especially incantations, which bore the influence of Christianity and which mention Christ or the Virgin Mary or other saints" (Porthan $1982,100)$.

Bengt af Klintberg claims that Swedish incantations developed under the influence of the formulae which spread from the Catholic monasteries in translations from Latin into the vernacular in the 10th and 11th centuries, and the chants for the banishing of demons and 
the blessings later officially favoured by the Church. The clergy began, for example, to recite them in the vernacular in order to drive out the incantations inherited from the pre-Christian era. Following the Reformation, the exorcisms and blessings favoured by the clergy were prohibited. By that time, however, they had already exerted a profound influence on both the popular contents of incantations and their mode of delivery (Klintberg 1980, $13 \mathrm{f}$.). In more recent centuries Sweden, too, witnessed a tendency towards low-voiced muttering in sharp contrast to the pompous grandiloquence of the Catholic era (Klintberg 1980, 11).

Following the example of Lencqvist, Finnish researchers of folk belief have described the incantation as a genre characterised by spoken delivery and a verbatim adherence to a traditional scheme (Hautala 1960, 21). The European incantations noted down in the past few centuries are indeed formulae with a seemingly mechanical effect. The performer aims not at personal contact with the other world or an opponent, but believes rather that he will achieve his goal through his command of secret knowledge and magic techniques. Anyone is capable of reciting an incantation, and the mode of delivery is of no vital significance. This description, however, only partially corresponds to the essence of the Finnish incantation tradition. F. A. Hästesko states that the incantations of Eastern Finland differ from those of the western tradition in their breadth and wordiness. They have also been characterised by a wealth of variation (Hästesko 1910, IV). These characteristics are reinforced by the tietäja institution which persisted late in the area. From what we know of the tietäjä's behaviour, the incantation uttered in a normal speaking voice is a late phenomenon. It also appears that the Eastern Finnish and Karelian tietäjä institution in particular retained elements of the pre-Christian, Scandinavian belief tradition longer than any other.

\section{The tietäjä ecstatic}

The tietäjätradition that still existed in Eastern and Northern Finland and Karelia even this century was once known in all parts of the country. Proof of this, for example, is the following account from South-west Finland published by Lencqvist in 1782:

If some complaint is to be induced or banished, the task is embarked on with horrifying and almost preposterous gestures, by means of the voice and movements of the body. A certain nobleman from the parish of Taivassalo 
suffering from a complaint of the foot was audaciously approached some years ago by a quack doctor who promised to heal him if he had faith in his hands. The sick man consented. The quack heated up the sauna and got together a number of sauna swithces made from the banches of many trees. As they entered the sauna, the quack first drove away with hideous gestures and sounds all the demons and evil spirits, brushing the ceiling, the walls and the floor with the switches. Then he heated the switches a little and, in the Finnish fashion, set about flaying the sick man's body, muttering his own incantations. This done, he cut the switches into very small pieces with a knife, gripped by tremendous wrath, dug a hole in the sauna floor and hid them from view. The nobleman often spoke of this later to his friends, with a laugh. For some days after the sauna he did in fact feel better, but the complaint did not disappear (Porthan 1982, 102).

The hideous gestures and "wrath" that astonished the nobleman were no random phenomenon. A tietäjä has to be "inspired", "possessed by spirits" or "in ecstasy" in order to wage a successful battle against a disease. Maura Marttini of Vuokkiniemi said that "when curing you have to leap in ecstasy, the greater the ecstasy, the better and more effective the spell" (SKS Marttini 1911). In a lexicon published in 1786 Christfrid Ganander explains the expression "to leap in ecstasy" as meaning being in the grips of a special spirit, a state akin to ecstasy.

In his work Mythologia Fennica, Ganander describes the state of the witch (noita) in a trance in colourful words: "No one dares to disturb these omniscient gentlemen, for they rage, clench their teeth, their hair stands on end, they leap about in excitement, mutter some words, stamp their feet and behave as if consumed by rage, and they are accordingly called Ecstatics" (Ganander 1789, 21). The most detailed account of the behaviour of a tietäjä is contained in the doctoral thesis of Elias Lönnrot: a tietäjä 1) rages, 2) his speech becomes loud and frenzied, 3) he foams at the mouth, 4) he clenches his teeth, 5) his hair stands on end, 6) he rolls his eyes, 7) he scowls, 8) he often spits, 9) he twists his body, 10) he stamps his feet, 11) he leaps up and down and 12) he makes many other such gestures (Lönnrot 1832, 11). The attention of observers has also been caught by the convulsions that set his body trembling (Hako 1954, 61; Kopponen 1973, 34) and the glassy stare that follows the rolling of his eyes (Koivu \& Tuovinen 1980, 178; Salminen 1931, 632).

These descriptions give some idea of the state of ecstasy entered into by the tietäjä - one astonishingly similar to the states of altered consciousness induced by violent movement and rhythmic music achieved by the shamans of Central and Eastern Siberia. These motoric trances, 
as they are called, take the form of hyperactiveness, and they do not necessarily infer loss of consciousness. In Siberia and Asia such states, also known as possession trances, are reached at séances at which the shaman's spirit helper enters his master's body. The shaman is then in a position to journey to the other world, though he does not always do so. The prevalent explanation for disease in the possession trance regions is that a disease demon has entered the patient's body, and in order to cure the patient, it is therefore sufficient to banish the demon.

Possession trance differs from altered states of consciousness induced by hysteria or hypnosis alone in that neurophysiological changes take place which can be measured by EEG. These changes are indicated, for example, by muscular jerks and tremors of the head and limbs (Siikala 1978, 43 f.; Prince 1968). The tietäjä's convulsions and the tremors that beset his body can in fact be interpreted as neurophysiological changes accompanying trance. Another characteristic of possession trance is a reduction in sensory perception, which explains the shaman's ability to handle burning and sharp objects. The Finnish tietäjä was also capable of corresponding feats (Paulaharju 1981, 221).

Like the shaman, the tietäjä preparing for his task would summon his supernatural powers by collecting his requisites and dressing for the rite. The tietäjä's shirt (SKS Lahtinen 1889), cap and belt have been regarded as vestiges of the ancient witch's costume (Honko 1960, 88). Sewn into the lining of the cap there might be a piece of leather from a diver (SKS Pulkkinen 1937) a squirrel (Paulaharju 1929, 178) or some other animal. The pouch hanging from his waist contained bones, bear's teeth and other such accessories required for healing, protection, etc.

There is proof that the somewhat rare references to the tietäjä's dress really do apply to an ancient tradition in the Icelandic saga, Eiriks saga rauða, noted down in the late 13 th century, but probably composed in the 12th century (Strömbäck 1935, 50-55). Threatened by starvation, the people of Greenland sought help from a seer by the name of Lillvolva, who set up a witch's séance. In addition to a cape and a staff he had a head-dress lined with white cat's fur, gloves of cat's fur and a belt from which hung a witch's pouch. Since the symbols attached to the witch's head-dress in the Northern Asian tradition represent helping spirit beings, it may be assumed that the skins sewn into the head-dress in both the Karelian-Finnish and the Icelandic traditions referred to helping spirits in the form of animals. Sometimes a snake might be sewn into the belt of the Archangel Karelian tietäjä for the same purpose. 
The tietäjä embarking on his task thus began by calling upon his spirits. This he did by means of various formulae and chants invoking his spirits and requesting help:

Nouše luontoni lovešta,

Havon alta haltiani,

Havon alta hattupiäššä.

Kiven alta kinnaš kiäšs̆ä!

(SKVR 1: 4. 11)
Rise, my guardian, from thy lovi, Wake, my spirit, once again, From under your tree, a hat on your head, From under your stone, a mitten on your hand!

We may deduce from the Icelandic description given above what these mysterious words mean. The ancient Scandinavian seið séance held by Lill-vglva links the behaviour of the tietäjä more closely with that of the shaman in the sense that contact with the spirits was obtained by means of songs, and supporting the witch was a band of assistants. On the seer's request, one of the women present sang a vardlo $(k) k u r$ song so beautiful that it attracted many spirits (nattúrur). Thus we also encounter the concept of "spirit" in connection with the Scandinavian seid séance. Its synonym, vard, indicates a guardian spirit of an individual person, household or family, a keeper or invisible companion imagined as having e.g. human form. The vardlo $(k) k u r$ song invokes the companions guarding the witch, her guardian spirits, and at the same time conducts him to a state of altered consciousness. Like Lillvolva, the tietäjä calls forth his spirit companions from their dwelling place somewhere in the other world. Like its master, the guardian spirit is fitted out with potent mittens and a hat.

The behaviour of the tietäjä is in many ways reminiscent of shamanic ecstasy. But the shaman appears in public, supported by an assistant and a chorus, and instead of spoken incantations resorts to rhythmical music and singing. Since the recitation of incantations as a means of attaining a state of trance is exceptional rather than general, we should give further thought to what the observations of Tuomo Jaakon poika on singing at a healing séance really meant.

\section{Were incantations sung?}

Elias Lönnrot explains in his lexicon (Lönnrot 1874-80, 1-2) that the word laulaa (to sing) was also used in connection with incantations: "uppläsa en trollformel, förtrolla genom trollformels uppläsande, signa; laulettu lakana, genom signeri försäkradt lakan." Y. H. Toivonen has 
further pointed out that in certain sayings singing has the meaning of 'exerting mysterious, magic-like influence', as in "päivä laulaa voin" (Toivonen 1944, $193 \mathrm{f}$.). The verb laulaa is used specifically to describe the delivery of incantations in the report of a court case at Kuolajärvi in 1671. The 80-year-old Aikie, son of Aikie from Kuusamo had tried to ensure a man luck in salmon fishing by drumming and singing (förmedelst Trumma och Laula eller Sjunga). Martti Haavio noted that the same verb was used by Gabriel Tuderus in the 1670s in describing the séance of some Lapp witches (att laula och sjunga; laulande; laulandet) (Haavio 1967, 323). The link between the words laulaa and loitsia would indicate that incantations were sometimes sung.

In chapter 13 of De poesi fennica H. G. Porthan points out that incantations are not poems in the conventional sense. They are called lugut because they are uttered more in a speaking voice than in song. It seems, therefore, that Porthan also knew something about the singing of incantations, although, like the other folklore scholars in the 18th century, he stresses that incantations were specifically recited in a speaking voice. It appears likely that incantation singing was no longer found in the western tradition areas in the 18th century. The concept that incantations are always spoken became established among folklore scholars. There is, however, conflicting evidence from Karelia and especially Archangel Karelia. Reports of collecting in the 19th century very often mention the singing of incantations (e.g. Niemi 1921, 1121). In describing a meeting with Huotarini Kostja A. A. Borenius says; "In singing to me his incantation poems he did, in the manner of a tietäjä, always keep a few 'words' (or lines) at the end of the poem for himself, so that the power of the incantation would not pass from him to me" (Niemi 1921, 1091). The omission of the lines indicates that the tietäjä really did conceive of his song as an incantation. That incantations were sung is also in dicated by the term tieto- or konstivirsi (information or means song) (Niemi 1921, 1108).

It is possible that incantations were sung in the manner of epic poems, with a chorus following a leader. Gottlund reports on how he got Samuel Nykytti of Vuokkiniemi to sing for him at Kuhmoinen in 1859: "And since there were several rune singers present, after the meal I got one of them with an accompanist, to sing the long poem (incantation) about the origin of the snake, to give the people of the region a chance to hear a song of this type" (Niemi 1921, 1178).

Was the singing of an incantation with an assistant merely a unique occurrence set up by Gottlund? It appeared at the assizes in Elimäki 
and Vehkalahti in 1643 that Erkki Matinpoika, accused of witchcraft - who while he was asleep could learn news of another parish had sung a "magic song" with another man while drunk at a St. Stephen's Day feast. It is very unlikely that this was one of the ritual poems recited on the day after Christmas to bring luck to the horses, because the host and the other guests angrily drove the singers out. The lines recalled by the host (Mäntylä 1969, 109) indicate that this was a variation of the St. Stephen's Day song devised with a view to mockery. We know from the parish of Heinola, for example, of the St. Stephen's Day song being sung "backwards" (SKVR 9: 1, 284).

There are also reports in incantations of chants being sung by a solo singer and a seconder. The song of Shimanaini Kipri, a Patvaska (tietäjä or matchmaker) from Archangel Karelia (SKVR 1: 4, 1873), tells how Väinämöinen harnessed a colt and rode to Lapland. There he meets a Lapp, who asks for a ride in the sleigh. The Virgin Mary brings the two of them some beer, after which the Lapp suggests that they "put their hands together". Placing a kantele or "song box" across his knees, he announces the purpose of the incantation: "Let us sing a bird from Lapland."

The Patvaska's song does in fact give a realistic description of the way runes were sung. On the other hand, it also contains the important external features of a shamanistic séance: anyone wishing to fall into a trance needed an assistant to bring him round again, an instrument as his medium and some stimulating substance to work him up into a state of frenzy. K. F. Karjalainen reports that the Ostyak witch had recourse not only to a drum but also to an instrument reminiscent of a five-stringed kantele (Karjalainen 1918, $565 \mathrm{f}$.). According to the shamanistic way of thinking the instrument bearing the shaman to ecstasy is a vehicle; in the Altaic regions the drum is called a horse, in the Arctic regions a boat. Calling the kantele a "song sleigh" (SK VR. 1: 4,481 ) reflects the same idea.

In what sorts of situations were incantations sung? Leea Virtanen, studying the Kalevala mode of singing, observed that it is difficult from written notes alone to draw any distinction between the spoken and the sung incantation, the epic song in Kalevala metre. She claims that singing in the function of an incantation is part of the preparatory stage of work (Virtanen 1968, 27). One factor helping to solve the problem of the sung incantation is its public or community nature. The ritual songs performed at the annual occupational festivals or various events in the course of work were part of the common heritage and their performance was not discouraged. The activities of the 
tietäjä, on the other hand, were founded on the secret knowledge at his command and encroached, what is more, on a region of the Christian faith that still shumned the public eye. On the other hand, seeking protection and appeasing the benevolent spirits, which assume the form of a song in various situations, featured among the special skills at the shaman's command. The above examples, like many of Virtanen's findings, further indicate that the poems of origin that were among the tietäjä's tools vere commonly sung. Turning to a song of origin in an attempt to resolve a crisis is also indicated in an incantation noted down by D. E. D. Europaeus at Uhtua, before a healing rite (SKVR 14: 1, 481).

Also giving some idea of the mode of performance are the names for incantation poems. Incantations of origin were very often called virsi; they were, therefore, sung. Luku suggests the spoken voice. Sanat poses something of a problem in that it can apply to both spoken delivery and to "verses" or holy words. Huotarini Kostja, among others, kept a few words or lines of his incantation to himself.

The most direct proof that incantations were originally sung is to be found in folklore itself. The tietäjä of narrative poetry and incantations is a "singer" who crushes his opponents by singing incantations (cf. Haavio 1967, 324 f.). The most descriptive accounts of sung incantations are given in Lemminkäinen's Adventures and the singing competition between Väinämöinen and Joukahainen. There are counterparts to this competition between masters on mythic knowledge in international folklore, the closest example being the quiz between Odin and Vaftrudner in ancient Scandinavian poetry (Siikala 1986). Like Odin, Väinämöinen proves himself superior in his knowledge of the birth or origin of phenomena, because he himself took part in their creation. The victorious Väinämöinen then sings Joukahainen into the swamp. Singing here means specifically the exerting of magic influence. It is not, however, a spoken luku; it is specifically a sung incantation such as that known by the Skolts as a levt. In 1926 Uno Harva noted down a story told by the Skolts of Petsamo in which some sons turned their mother into a stone by means of a levt song. He notes that although Genetz, in his lexicon of the Lapp dialects of the Kola Peninsula, describes a levt as a wordless song, he does recollect hearing words, too, though the melody was more important (Harva 1935, 42 f.).

The laulu or song of the Finns and the levt of the Skolts probably resembled the incantation singing known by the ancient Scandinavians as galdr. Odin was galdrarnas fader, i.e. the father of incantation 
singing, just as he was also the finest expert on poetic inspiration, magic arts and mythical knowledge, The galdr resembled the shamanistic song in the way it was performed. It was sung in a high register, in a voice reminiscent of the sound of a diver or a bird of prey, as was witnessed by the Roman Emperor Julianus on hearing Teutonic soldiers singing on the Rhine in the year 360 A.D. (Ohlmarks 1963, 40). Gala specifically meant influencing through singing: the Swedish word galen, meaning crazy, originally referred to the state of a person bewitched by singing (Klintberg 1980,11). Since the verb gala also means shouting and shrieking and the sound made by a bird, such as the crowing of a cock, it has been assumed that the galdr was performed something in the manner of a joiku (Klintberg 1980, 11). Few galdrs have been preserved in proportion to other ancient Scandinavian poetry; people tried to keep them secret in order to preserve their potency. Snorre Sturlason has, at Hattatál, nevertheless described their poetic metre, which was extremely complex and incorporated three types of rhyme. Alliteration, for example, was used to enhance the magic potency.

The context in which galdrs were sung is indicated by the poem Grogaldr, in which a boy called Svipdag fetches the words of an incantation from his witch-mother already in her grave. The theme as such is reminiscent of Väinämöinen's visit to the grave of Vipunen. The poem gives several hints that the roots of both the invocation of the spirits by the tietäja and the ecstatic words of the singer lead back to early incantation singing. The witch teaches her son the fateenticing song (ödets locksang), which helps him wherever he goes. This is a summoning of the spirit similar to the vardlo( $k) k$ kur sung at the seid mentioned above (Ohlmarks 1948, 307). The lack of a spirit of happiness is likewise bemoaned by the singer in this Ingrian poem:

Minun on onneni ojassa lykkyni lylyssä puussa, haon alla haltiani...

(Salminen 1943, 210).
My happiness is in the ditch My fortune far off in a tree, My guardian spirit hidden beneath a trunk

Although Väinö Salminen did not believe that the Finns once sang incantations, he nevertheless points out the link between the 'singer's words' and the incantations invoking the spirits (Salminen 1943). He is right in assuming that the common factor is the pursuit of ecstasy: both the reciter of the incantation and the singer of the rune had to be in a state of ecstasy. Thus the singer's words also include lines 
invoking the spirits (Salminen 1943, 210). The singer also boasts of being able to sing incantations, of achieving wonders with his singing (SKVR 1: 3, 1315).

The singer's words do not speak of true magic influence: their light, merry style expresses the singer's joy. They do, however, have a surprising number of similarities with the invocations of spirits, boasting and protection charms of the tietaija. One of these is a description of the place of performance; both the chanter and the singer take up their position on a stone, "a low stone", "a joyful stone", etc. The dead witch in Grogaldr tells her son the correct performance of the galdr: "When singing galdrs I stood on a stone in the ground, just inside the door." This was not just any stone; it was a stone beneath which the guardian spirits resided. According to Reichborn-Kjennerud there were similar beliefs attached to the threshold (Reichborn-Kjennerud 1928, 1, 4). Later Scandinavian incantations also mention chanting on a stone set in the earth. We also know that in Norway blood was staunched while sitting on a stone such as this ( $\AA$ A Knuts 1974, 39). Magic stones are also encountered in later Swedish folklore as the place for driving out diseases, "under sten och stock". Reichborn-Kjennerud explains that this derives from the guardian spirits attached to the stone. These were believed to take possession of the disease and make it harmless. We now see why the tietajja called forth his spirits from "under a stone" or "under a tree", or why a gate or a threshold were typical places for seeking protection in North European folklore. We also see that the ancient Finnish tietäjä achieved ecstasy by singing.

\section{The tietajä and the shaman}

In examining the way in which incantations were performed I came to the same conclusion as Kaarle Krohn: incantations delivered in a speaking voice are part of the tradition that became established in the Middle Ages. Short incantations were presumably used even before this, but in the pre-Christian era the singing of incantations demanding an ecstatic delivery was among the tietäja's tools. In function, this resembled the ancient Scandinavian galdr. On the other hand, the tietäja's requisites, the chants summoning the spirit and his ecstatic behaviour call to mind the ancient Scandinavian seid institution, even though the trance technique of the tietäjä differed from the events of the seid. 
Was the singer-tietäjä also a shaman? Was he able to travel to the other world? Like Finnish narrative poetry, ancient Scandinavian poetry and the fornaldrasaga tradition prove the existence of shamanistic phenomena differing from the Lapp noaide or witch tradition in Northern Europe in the Viking era and at the time of the Crusades. Martti Haavio has presented considerable evidence on behalf of Finnish shamanism. I shall not go into this here; I would, however, mention that the concepts noita or witch (which has a counterpart among e.g. the Voguls), langeta loveen, meaning to go into a trance or to lose consciousn ess, and kannus meaning a witch's drum demonstrate that the Finns do have their own names for the chief shamanistic phenomena. I will turn, instead, to a point only touched on by Haavio. Elias Lönnrot says in the foreword to his collection of the Incantations of the Finnish People:

Sitting on a stone, the tietajä's were said to travel across rivers and lakes, and their souls, detached from their bodies, travelled in other remote places, obtaining knowledge and then after some time were again united with their bodies. They prepared for such voyages of the spirit by quietly humming some magic poem, thereupon falling into a trance, and while the soul was travelling independently, the body, like a spiritless body at least, lay as if dead, to recover again on the return of the soul from its journeys (Lönnrot 1880, VII).

Since the origin of this information is not clear, Haavio assumes that Lönnrot was misled into describing the trance of a Lapp noita witch. This does not seem very likely, for Lönnrot particularly mentions that the Finns were not known to use a drum. Since the information in the foreword is in other respects well in keeping with reality, why would he have made a mistake over just this? The image of witches travelling on a stone are to be found both in the legend tradition and in narrative poetry. It is founded on the beliefs and practices surrounding reciting on a stone that are described above. The witch chanting on a stone fell into a state of ecstasy; during his ecstasy his soul might leave his body. In cases where the origin of a disease was not obvious or codified by the poetic tradition, the witch would undoubtedly travel in a trance to the other world to discover it. In Lapland, as in Siberia, dream may have taken the place of loss of consciousness as a means of acquiring knowledge.

The means of ecstasy employed by the Finnish noita was singing. He probably also used some kind of musical instrument. At the earliest stages this was, in keeping with the hunting cultures of northern 
Eurasia, undoubtedly a drum. The use of a drum in fact continued to be common among the Finns for a long time. In 1663 the northern witch Antti Tokoi told the court that he possessed a drum that had once belonged to a Lapp (Luho \& Luukko 1957, 495). A type of drum with a name only in Finnish has also been found in the area of Lapland around Kemi. In the pre-Christian culture described in the Kalevala epic and familiar to us from archaelological research in Karelia and Western Finland, the shaman's medium was a kantele (and possibly also a drum). As the poem about Väinämöinen's playing says, the sound of the kantele conjured forth not only people but also the spirits of the forest and the water. Stringed instruments were used as a means of attaining ecstasy not only in Europe but in Western Siberia, too.

More important to the shaman than his instrument, however, was his assistant, who reiterated all he said and took over the singing when he fell unconscious. The original meaning of the word runo (which today means a poem) was 'magic sign, incantation'. Originally rune singing thus literally meant the singing of incantations. It appears that, like epic poems, incantations were sung with an assistant. Thus the delivery of both the epic and the incantation would have common roots that ultimately lead back to the shamanic séance.

\section{Bibliography}

UNPUBLISHED SOURCES AND LITERATURE

\section{Helsinki}

SKS Suomen Kirjallisuuden Seura

Collections of the Folklore Archive of the Finnish Literature Society.

Lahıtinen, E. 62. Peräseinäjoki, 1889.

Marttini, I. b) 1042. Vuokkiniemi, Kivijärvi, 1911.

Pulkkinen, H. 739. Pielavesi, 1937.

Turku

$\AA \mathrm{A}$ Åbo Akademi, Religionshistoriska institutionen

Knuts, Ulrika. 1974. Begreppen folkreligion, universalreligion, folktro i belysning av föreställningar om jungfru Maria i nordiska trollformler. (Licentiate thesis). 


\section{PUBLISHED SOURCES AND LITERATURE}

Ganander, C. 1937 (1786). Nytt finskt lexicon 1. [Facsimile ed.] Porvoo.

- 1789. Mythologia Fennica. Åbo.

Haavio, M. 1967. Suomalainen mytologia. Porvoo.

Hako, M. 1954. Tietomiehiä ja tarinantaitajia. Karjalan heimo 5-7. Helsinki. Harva, U. 1935. Vanhan kansan loitsulauluista. Kalevalaseuran vuosikirja 15. Porvoo.

Hautala, J. 1960. Sanan mahti. Jumin keko. [Ed. by] J. Hautala. (Tietolipas 17.) Forssa

Honko, L. 1960. Varhaiskantaiset taudinselitykset ja parantamisnäytelmä. Jumin keko. [Ed. by] J. Hautala. (Tietolipas 17.) Forssa.

Hästesko, F. A. 1910. Länsisuomalaiset tautien loitsut. Helsinki.

Juvelius, E. W. 1930. Elämää Suomessa 1600-luvulla. (Suomen kansan aikakirjat 4.) Helsinki.

Karjalainen, K. F. 1918. Jugralaisten uskonto. (Suomensuvun uskonnot 3.) Porvoo.

Klintberg, B. af 1980. Svenska trollformler. Stockholm.

Koivu, L. \& Tuovinen, P. 1980. Tietomies Valtimolta. Kertojat ja kuulijat. [Ed. by] P. Laaksonen. (Kalevalaseuran vuosikirja 60.) Helsinki.

Kopponen, T. 1973. Tietäjä, Heikki Hurstisen toiminnan tarkastelua. Helsinki.

- 1976. Parantajat. Forssa.

Luho, V. \& Luukko, A. 1957. Suur-Lohtajan historia 1. (Keski-Pohjanmaan historiasarja 3.) Kokkola.

Lönnrot, E. 1832. Om finnarnes magiska medicin. Åbo.

- 1874-80. Suomalais-ruotsalainen sanakirja 1-2. Helsinki.

- 1880. Suomen kansan muinaisia loitsurunoja. Helsinki.

Mäntylä, I. 1969. Ja yhteinen rahvas todisti. Porvoo.

Niemi, A. R. 1921. Vienan läänin runonlaulajat ja tietäjät. Helsinki.

Ohlmarks, А. 1948. Eddans gudasånger. Uppsala.

- 1963. Asar, vaner och vidunder. Stockholm.

Paulaharju, S. 1929. Vienan Karjalan tietäjistä. Kalevalaseuran vuosikirja 9. Helsinki.

- 1981. Suomenselän vieriltä. Porvoo.

Piela, U. 1983. Muuttumaton tautiloitsu?. Kansa parantaa. [Ed. by] P. Laaksonen \& U. Piela. (Kalevalaseuran vuosikirja 63.) Helsinki.

Porthan, II. G. 1982. Valitut teokset. (Suomalaisen Kirjallisuuden Seuran toimituksia 373.) Jyväskylä.

Prince, R. 1968. Can the EEG be used in the study of possession states? Trance and possession states. Ed. by R. Prince. Montreal.

Reichborn-Kjennerud, I. 1928. Var gamle trolldomsmedisin 1. (Skrifter utg. av Det Norske Videnskaps-Akademi i Oslo, 2, Iist. Fil. Klasse 1927, 6.) Oslo.

Salminen, V. 1931. Inkerin runonlaulajat ja tietäjät. Suomen kansan vanhat runot 5, 3. Helsinki. [Offprint.] 
Salminen, V. 1943. Sanan voima ja laulajan intoutuminen. (Suomi-kirjan eripainoksia 12, Uusi sarja.) Helsinki.

Siikala, A.-L. 1978. The rite technique of the Siberian shaman. (FF Communication 220.) Helsinki.

- 1986. Shamanistic themes in Finnish epic poetry. Traces of the Central Asian culture in the North. [Ed. by] I. Lehtinen. (Mémoires de la Société Finno-ougrienne 194.) Helsinki.

SKVR Suomen kansan vanhat runot 1-14. 1908-48. (Suomalaisen Kirjallisuuden Seuran toimituksia 121-151.) Helsinki.

Strömbäck, D. 1935. Sejd. (Nordiska texter och undersökningar utg. i Uppsala av Bengt Hesselman 5.) Stockholm.

Toivonen, Y. H. 1944. San at puhuvat. Porvoo.

Virtanen, L. 1968. Kalevalainen laulutapa Karjalassa. Helsinki.

Wartiainen, E. 1926. Taikamaitten kansaa. Sortavala. 